\title{
Student interaction with Open Journal System based on ISO 9241-110
}

\author{
I S Rahayu, R Hartanto, A P Wibawa \\ Vacational Education \\ State University Malang \\ Malang, Indonesia
}

\author{
D Meirawan \\ Building Engineering Education \\ Indonesia University of Education \\ Bandung, Indonesia
}

\author{
E Nugraha \\ Computer Science Department \\ Indonesia University of Education \\ Bandung, Indonesia
}

\begin{abstract}
Open Journal System (OJS) is rapid grown open source system that is used to support and manage online journal publication. Problems interaction between the users and the system appear since many users finding difficulty to use OJS. ISO 9241-110 becomes a standard in the aspect of human interaction with the system that focuses on the principle of dialogue. This paper use survey research method and descriptive statistic for analyzing the data. Based on the survey results using questionnaires, it is known that OJS has met ISO 9241-110 standard. Meanwhile, there are some indicators that need further improvement based on the results of the study.
\end{abstract}

\section{INTRODUCTION}

The Open Journal System (OJS) is an open source platform,widely used to support and manage online journal publication [1]. OJS is developed by Public Knowledge Project (PKP) [2].OJS manages journal workflow from manuscripts, editorial, until publication stages [3]. The OJS is easy to be installed on the local web server and used on various operating system platforms, easy installation, and has a lot of documentations[4]. OJS becomes a solution to manage and publish journal and save publishing cost[5]. One of its advantages, OJS is better than non open access journal[6]. However there is no evidence of the interaction level between OJS and its user.

Therefore the study aims to discuss the OJS interaction with users in terms of ergonomic aspects based on ISO 9241110 standard. In the early observation activities, some problems were found such as less number of OJS users, many users who have difficulty in using OJS, and low intensity of users in reading the journal using OJS. Those problems are discussed in this paper as indicators. In another word, this paper will discuss students' interaction with OJS version 2.4.7.0 based on ISO 9241-110.

\section{ISO 924-110: DIALOGUE PRINCIPLE}

International Organization for Standardization (ISO) is a guidance for establishing and evaluating the quality of products, systems and services based on organizational goals [7]. It guides consistency, capability and security which relates to aspects of usability or human interaction with the system [8]. In particular ISO is provided to help human to interact with system.

ISO 9241-110:2006 sets for ergonomic design principles that is formulated in general terms and provides a framework for applying those principles to the analysis, design and evaluation of interactive systems. This ISO focuses on dialogue principles related to the ergonomic design of the dialogue between user and interactive system. It does not consider any other aspects of design such as marketing, aesthetics or corporate design[9]. Dialogue principle or user-computer interfacing can be used as good reference to guarante that the developed design offer good user experience [10].

There are seven Indicators of dialogue principles in ISO 9241-110, they are[11]: 1) suitability for the task; 2) selfdescriptiveness; 3) conformity with user expectations; 4) suitability for learning; 5) controllability; 6) error tolerance; and 7) suitability for individualization.

The first indicator is the suitability for the task. The main function of open system journals is to facilitate academics in doing online publications. The existence of OJS is expected that academics can easily publish efficiently. In order for efficiency to be achieved, OJS does not require unnecessary input, so academicians who are eager publish their work do not spend the time to fill in unexpected inputs.

The second is self descriptiveness, OJS have a consistent design to provide convenience to the users when accessing the system. In addition, the system can also provide them the status information and where the current position of the users. It should be clear which part of the system they use, where they are in the dialog, which actions can be taken and how they can be done.

The third is conformity with user expectations, OJS provides suitable information which meets the users' expectation. The information provided by the system is the information required by the users, so the data will not appear if it is not required by them. When the information desired by the users is not suitable to the data possessed by the system, then the system provides information to the users. The main thing is that the system provides information in accordance with the interest and choice of the users.

The fourth is suitability for learning, the system should be user-friendly designed. Thus, the users do not need a long time to learn the use of icons, the available menus, and the system data flow.

The fifth is controllability, the users should be able to start and determine the direction to the point where the destination has been met. Inter menu which is provided is enough to help the users in making the switch. The menu options provided are work-runs. 
The sixth is error tolerance.User input errors are normal, so the system provides a function to correct the errors. When the users make an input error, the system gives an error message that can be easily understood by the users. Although there is an error in the input, the desired result must be achieved with no or minimal corrective action by the users.

The seventh is suitability for individualization.The system is designed based on the needs of the users. The system is also adaptable to the user tasks with a scope that can also be adapted to the needs of the users. The system allows the users to modify the interaction and presentation of information to suit their individual capabilities and needs.

\section{METHOD}

This research aims to survey the use of OJS in Universitas Negeri Malang (UM). The stages of this research had adapted the survey stages based on Cresswell [12]. The following were the stages used in this study: (1) Determining that survey research is a suitable design that describes human-system interaction based on ISO 9241-110. (2) Identifying the formulation related problem with how the user interact with the OJS in the aspect of ergonomics based on ISO 9241-110. (3) Identifying population (post-graduate students in UM), and framing sample from post-graduate students who came into journal room, done for 2 weeks starting from date 16-27 April 2018. (4) Determining survey design and data collection procedures i.e data collection conducted by using interviews and questionnaires. (5) developing and determining the instrument which were in the form of questionnaires adopted from ISONORM 9241/110 [13], where the respondents gave answers according to their opinion for each item on a sevenpoint scale with a description in both sides. The items then were evaluated on a bipolar scale optimally at the midpoint and on a unipolar scale optimally at one or the ends. (6) Managing instruments i.e adjusting the language from English into Indonesian. (7) Analyzing data by referring to the research problems i.e data obtained in the form of qualitative and quantitative data. They were then processed using descriptive statistic analysis techniques. Descriptive statistics were used to analyze data by deciphering the data to make it easier to understand. Conclusions from descriptive statistics cannot be used in a broad population, and can only be used in existing data samples.; and finally (8) writing a report.

\section{RESULT AND DISCUSSION}

After performing data collection to the respondents, then data analysis was conducted descriptively. The following are the results of the data collection of respondents.

TABLE I. FREQUENCY DISTRIBUTION SUITABILITY FOR THE TASK

\begin{tabular}{|c|c|c|c|c|c|c|c|c|c|c|}
\hline \multirow{3}{*}{$\begin{array}{l}\text { Indicator } \\
\text { Suitable } \\
\text { for the } \\
\text { task }\end{array}$} & & \multicolumn{9}{|c|}{ Frequence (User) } \\
\hline & Item & 1 & 2 & 3 & 4 & 5 & 6 & 7 & Total & Average \\
\hline & $\begin{array}{l}\text { Necessary } \\
\text { function }\end{array}$ & 0 & 2 & 3 & 11 & 10 & 13 & 1 & 40 & 4.80 \\
\hline & $\begin{array}{l}\text { Unnecessary } \\
\text { input }\end{array}$ & 1 & 2 & 5 & 12 & 12 & 7 & 1 & 40 & 4.43 \\
\hline & $\begin{array}{l}\text { Demand of } \\
\text { the work }\end{array}$ & 0 & 1 & 5 & 7 & 14 & 12 & 1 & 40 & 4.85 \\
\hline
\end{tabular}

Based on the results in table 1, it could be interpreted that the indicator of suitability for the task was categorized as quite well with an average scale of more than 4 or near 7 . The function on OJS was quite satisfactory for the writer. However, based on the comments added by respondents, the OJS had not provided responsive web design. It caused the readers to have a lot of efforts to read the article on the OJS when using a Smartphone. In fact, the reaserch done by [14] find that user had a better experience with smartphone than with personal computer. But user like authors is advised to use the OJS through desktop, because it will be easier to interact with the system.

Table 2. Frequency distributionof Self Descriptiveness

\begin{tabular}{|l|l|c|c|c|c|c|c|c|c|c|}
\hline & & \multicolumn{7}{|c|}{ Frequence (User) } \\
\hline Indicator & Item & 1 & 2 & 3 & 4 & 5 & 6 & 7 & Total & Average \\
\hline $\begin{array}{l}\text { Self } \\
\text { descriptiveness }\end{array}$ & $\begin{array}{l}\text { Oriented } \\
\text { design }\end{array}$ & 1 & 0 & 5 & 9 & $\mathbf{1 4}$ & 10 & 1 & 40 & 4.73 \\
\hline & $\begin{array}{l}\text { Insight } \\
\text { regarding } \\
\text { its } \\
\text { current } \\
\text { status }\end{array}$ & 1 & 1 & 4 & 11 & 11 & $\mathbf{1 2}$ & 0 & & \\
\hline & $\begin{array}{l}\text { Designed } \\
\text { according } \\
\text { to a } \\
\text { consistent } \\
\text { principle }\end{array}$ & 0 & 0 & 2 & 9 & $\mathbf{1 9}$ & 8 & 2 & 40 & 4.65 \\
\hline
\end{tabular}

In table 2, It is known that self descriptiveness in the OJS was in quiet well category with an average scale exceeding 4. The OJS provided sufficient explanation for the users about the function of the system itself due to the consistent design. The consistent OJS design allowed users to access it repeatedly. The OJS also provided enough information about the status of the users when accessing the system, so the users could know the position at that time.Thus, the OJS had fulfilled the principles of self-descriptiveness.This finding is similar with previous research done by [10] that self descriptiveness is the part of usability element. Usability is also defined as set of attributes that must be designed into software to make it easy to use.

Table 3. Frequency distributionof Conformity with user expectations

\begin{tabular}{|l|l|c|c|c|c|c|c|c|c|c|}
\hline & & \multicolumn{7}{|c|}{ Frequence (User) } \\
\hline Indicator & Item & 1 & 2 & 3 & 4 & 5 & 6 & 7 & Total & Average \\
\hline $\begin{array}{l}\text { Conformity } \\
\text { with user } \\
\text { expectations }\end{array}$ & $\begin{array}{l}\text { Valid and } \\
\text { necessary data }\end{array}$ & 1 & 3 & 1 & 11 & 9 & $\mathbf{1 4}$ & 1 & 40 & 4.75 \\
\hline & $\begin{array}{l}\text { Provide on } \\
\text { request context } \\
\text { of sensitive } \\
\text { explanations }\end{array}$ & 1 & 2 & 1 & 8 & 13 & $\mathbf{1 5}$ & 0 & 40 & 4.88 \\
\hline & $\begin{array}{l}\text { Automatically } \\
\text { offer context } \\
\text { of sensitive } \\
\text { explanations }\end{array}$ & 1 & 1 & $\mathbf{1 4}$ & 2 & 13 & 8 & 1 & 40 & 4.33 \\
\hline
\end{tabular}

Based on table 3, it is known that the OJS had fulfilled the principles of conformity with user expectation that they can find the needed information. It is because the average scale obtained exceeds 4. However, there is one item that gave assessment under the scale of 4, i.e. on the item of "automatically" which offers context sensitive explanation. Based on the table 3, it is known that the OJS provided valid information (article title) in accordance with the information 
required by the users. But, OJS did not display the users information suggestions when the information that they were looking for was not found, so the users did not get any information according to their interest.

Table 4. Frequency distribution of Suitability for learning

\begin{tabular}{|l|l|l|l|l|l|l|l|l|l|c|}
\hline & & \multicolumn{7}{|c|}{ Frequence (User) } \\
\hline Indicator & Item & 1 & 2 & 3 & 4 & 5 & 6 & 7 & Total & Average \\
\hline $\begin{array}{l}\text { Suitability } \\
\text { for } \\
\text { learning }\end{array}$ & Time to learn & 0 & 4 & $\mathbf{1 6}$ & 6 & 5 & 5 & 4 & 40 & 4.08 \\
\hline & $\begin{array}{l}\text { Memorization } \\
\text { of many } \\
\text { design }\end{array}$ & 0 & 2 & $\mathbf{1 2}$ & 6 & 10 & 4 & 6 & 40 & 4.50 \\
\hline & $\begin{array}{l}\text { Learn without } \\
\text { external } \\
\text { support }\end{array}$ & 1 & 3 & 5 & 4 & $\mathbf{1 5}$ & 9 & 3 & 40 & 4.70 \\
\hline
\end{tabular}

The principles of suitability for learning on OJS based on table 4 were included in quite well category with an average scale near 7. Then, the OJS had fulfilled the principles of suitability for learning that can facilitate the users when using the system, but further improvement is still needed. In the items of "time to learn" and "memorization of many designs" respectively, users took a lot of time to learn and memorize the functions that the OJS has provided. Although it spends longer time to learn the OJS functions, users did not find any significant problems in learning the OJS without external support or guide books.

Table 5. Frequency distribution of Controllability

\begin{tabular}{|l|l|l|l|l|l|l|l|l|l|l|}
\hline & & \multicolumn{7}{|c|}{ Frequence (User) } \\
\hline Indicator & Item & 1 & 2 & 3 & 4 & 5 & 6 & 7 & Total & Average \\
\hline $\begin{array}{l}\text { Control- } \\
\text { lability }\end{array}$ & $\begin{array}{l}\text { Follow an } \\
\text { unnecessarily } \\
\text { rigid } \\
\text { sequence of } \\
\text { steps }\end{array}$ & 0 & 3 & 5 & 7 & $\mathbf{1 3}$ & 10 & 2 & 40 & 4.70 \\
\hline $\begin{array}{l}\text { Easy } \\
\text { switching } \\
\text { between } \\
\text { individual } \\
\text { menu or } \\
\text { mask }\end{array}$ & 1 & 1 & 6 & $\mathbf{1 2}$ & $\mathbf{1 2}$ & 7 & 1 & 40 & 4.45 \\
\hline $\begin{array}{l}\text { Entails } \\
\text { unnecessary } \\
\text { interruptions } \\
\text { of the work } \\
\text { flow }\end{array}$ & 1 & 0 & 8 & 10 & $\mathbf{1 4}$ & 7 & 0 & 40 & 4.43 \\
\hline
\end{tabular}

From table 5, it is known that the principle of controllability is in the good category with an average scale of more than 4. This showed that the users can control the dialog with the OJS, so the users can determine the direction. When using the OJS, the users were not forced to follow the sequence of unnecessary steps. Users stated that the switch menu provided by OJS made them easy to know its current position, and the steps provided by OJS were workflows so that it did not require workflow interruptions.
Table 6. Analysis Indicator of Error Tolerance

\begin{tabular}{|l|l|l|l|l|l|l|l|l|l|c|}
\hline & & \multicolumn{10}{|c|}{ Frequence (User) } \\
\hline Indicator & Item & 1 & 2 & 3 & 4 & 5 & 6 & 7 & Total & Average \\
\hline $\begin{array}{l}\text { Error } \\
\text { tolerance }\end{array}$ & $\begin{array}{l}\text { Provides } \\
\text { error } \\
\text { messages }\end{array}$ & 0 & 4 & $\mathbf{1 4}$ & 12 & 6 & 3 & 1 & 40 & 3.83 \\
\hline & $\begin{array}{l}\text { Error } \\
\text { correction }\end{array}$ & 0 & 2 & $\mathbf{1 8}$ & 7 & 4 & 5 & 4 & 40 & 4.10 \\
\hline & $\begin{array}{l}\text { Concrete } \\
\text { help for } \\
\text { error } \\
\text { correction }\end{array}$ & 0 & 0 & $\mathbf{1 3}$ & 7 & 6 & 11 & 3 & 40 & 4.60 \\
\hline
\end{tabular}

In this principle based on table 6 it is known that there is an average on the scale of 3.83 indicating that the item is on a less good scale. OJS did not provide user-required facilities, such as error messages and repair suggestions, so that the user did not get the required information. The error message provided was less understandable, so the user could not determine the fix one and this made the users took longer time to make error corrections. Based on the comment added by respondent, it is stated that the OJS did not provide concrete help to correct the errors. So the principle of error tolerance is still not well. This problem just applied in finding article title. But, for error in entering username and password, OJS has showed error massage which can be understood by the user.

Table 7. Analysis Item of Suitability for Individualization

\begin{tabular}{|l|l|l|l|l|l|l|l|l|l|c|}
\hline & \multicolumn{7}{|c|}{ Frequence (User) } \\
\hline Indicator & Item & 1 & 2 & 3 & 4 & 5 & 6 & 7 & Total & Average \\
\hline $\begin{array}{l}\text { Suitability for } \\
\text { individualization }\end{array}$ & $\begin{array}{l}\text { Expand } \\
\text { new task }\end{array}$ & 0 & 3 & 4 & 11 & $\mathbf{1 3}$ & 8 & 1 & 40 & 4.55 \\
\hline & $\begin{array}{l}\text { Adapt to } \\
\text { individual } \\
\text { working } \\
\text { style }\end{array}$ & 0 & 1 & 6 & 11 & $\mathbf{1 3}$ & 7 & 2 & 40 & 4.63 \\
\hline & $\begin{array}{l}\text { Scope to } \\
\text { adapt for } \\
\text { different } \\
\text { tasks }\end{array}$ & 1 & 4 & 5 & 10 & $\mathbf{1 1}$ & 8 & 1 & 40 & 4.35 \\
\hline
\end{tabular}

From Table 7 it is known that OJS had fulfilled the principle of suitability for individualization, the average scale obtained is more than 4 . The users could modify the presentation of information according to the users' needs. The OJS could also be used according to the users' needs, i.e. as author or readers. However, not all interactions can be modified, such as the submit stage of the narrative that must be in accordance with the workflow.

\section{CONCLUSION}

Implementation of the ISO 9241-110 dialogue principle can be considered in system design as a direction for analysis, design, implementation, and testing. Open system journals have been developed in accordance with this rule; this is the evidence from the results of the questionnaire which states that the indicators on the principle of ISO 9241-110 dialogue have a good response. However, there are indicators of some principles that still do not meet the expectation. First, the principle of suitability for the task; the system did not provide responsive web functionality for the users when they use Smartphone. This causes the users to take a long time to adapt to the web display on the Smartphone. However, when the users use the OJS as author, it is more efficient to use personal 
computer. Second, the OJS does not provide any advices to the users when the information they need is not available in the system. Third, the users take a lot of time to understand the functions provided by the OJS because the function layout available on the OJS has not provided a good user experience. Fourth, the system does not provide error messages and suggestions improvements to the user, so the users take a lot of time to make improvements. Therefore, the result of this research can not be generalized. Because this research is limited on OJS user in Universitas Negeri Malang, researchers can further conducting more in-depth reasearch in term of user' interaction with OJS. So, there must be further research with more number of samples and more research sites.

\section{REFERENCES}

[1] N. Homenda and S. Pekala 2018 "Migrate, Publish, Repeat: TEI Journals in the Open Journal Systems Platform," no. 10, pp. 0-17

[2] I. Arief and H. Handoko 2016 Jurnal Online dengan Open Journal System

[3] V. Nagaraj 2009 "Open Access Journal Publishing in India: A study with OJS Software," Online, pp. 479-484

[4] “Open Journal System (OJS) 3.0 Evaluation," 2014

[5] J. Willinsky 2005 "Open Journal Systems: An example of open source software for journal management and publishing," Libr. Hi Tech vol. 23, no. 4 , pp. $504-519$

\section{Research Instrument}

\section{ISONORM 9241/110-S}

Evaluation of software based upon

International Standard ISO 9241, Part 110 "Ergonomics of human-system interaction - Dialogue principles"

In the following, you are kindly requestedto evaluate software based upon the International Standard

ISO 9241, Part 110 "Ergonomics of human-system interaction -Dialogue principles".

Please readcarefully:

$\square$ The goal of this evaluation is to detect weaknesses insoftware and to develop concrete suggestions for improvement.

$\square$ In order to achieve this, your judgement as userof aspecific software program is of paramount importance. Your evaluation of the software inquestion should bebased on your personal expe- rience.

$\square$ It is importantto remember that this is notan evaluation of you personally. Rather, we are inter- ested in your personal evaluation of the software youare working with.

$\square$ First of all, please give ussomespecificationsof the type of software you are going to evaluate in the box below.

Which software are you going to evaluate? (Please decide onone software program only!):

Name of the software : Open Jurnal Sistem (OJS) Pascasarjana Universitas Negeri Malang

Version number : 2.4.7.0

Producer

Component /Module

- Howlong haveyou been working with the evaluated software? month(s)

- On average, howmany hoursper day do you work with the evaluated software? hours/days

- How well do you knowthe evaluated software?. very well 


\begin{tabular}{|c|c|}
\hline $\begin{array}{l}\text { 1. does not offer all necessary } \\
\text { functions to efficientlymaster all } \\
\text { given tasks }\end{array}$ & $\begin{array}{l}\text { offers all necessary functions to } \\
\text { efficientlymaster all given task }\end{array}$ \\
\hline 2. requires unnecessary input & $\begin{array}{l}\text { does not require unnecessary } \\
\text { input }\end{array}$ \\
\hline $\begin{array}{l}\text { 3. inappropriatelymeets the demands } \\
\text { ofthe work }\end{array}$ & $\begin{array}{l}\text { appropriatelymeets the demands } \\
\text { ofthe work }\end{array}$ \\
\hline $\begin{array}{l}\text { 4. provides insufficient information } \\
\text { about which entries are valid and } \\
\text { necessary. }\end{array}$ & $\begin{array}{l}\text { provides sufficient information } \\
\text { about which entries are valid } \\
\text { and necessary }\end{array}$ \\
\hline
\end{tabular}

\begin{tabular}{|c|c|c|}
\hline The software ... & $-1+\quad+\quad++\quad+++$ & The software ... \\
\hline $\begin{array}{l}\text { 5. does not provide on request context- } \\
\text { sensitive explanations, which are } \\
\text { concretely helpful. }\end{array}$ & & $\begin{array}{l}\text { does provide on request } \\
\text { context-sensitive } \\
\text { explanations, which are } \\
\text { concretely helpful. }\end{array}$ \\
\hline $\begin{array}{l}\text { 6. does not automaticallyoffer context- } \\
\text { sensitive explanation, which are } \\
\text { concretely helpful. }\end{array}$ & & $\begin{array}{l}\text { does automaticallyoffer } \\
\text { context-sensitive } \\
\text { explanation, which are } \\
\text { concretely helpful. }\end{array}$ \\
\hline $\begin{array}{l}\text { 7. complicates orientation due to an } \\
\text { inconsistent design. }\end{array}$ & & $\begin{array}{l}\text { facilitates orientation } \\
\text { due to a consistent } \\
\text { design. }\end{array}$ \\
\hline $\begin{array}{l}\text { 8. provides insufficient insight regarding its } \\
\text { current status }\end{array}$ & & $\begin{array}{l}\text { provides sufficient } \\
\text { insight regarding its } \\
\text { current status }\end{array}$ \\
\hline $\begin{array}{l}\text { 9. is not designedaccording to a consistent } \\
\text { principle. }\end{array}$ & & $\begin{array}{l}\text { Is designedaccording to } \\
\text { a consistent principle. }\end{array}$ \\
\hline 10. requires a lot oftime to learn. & & $\begin{array}{l}\text { requires little time to } \\
\text { learn }\end{array}$ \\
\hline $\begin{array}{l}\text { 11. requires thememorization of too many } \\
\text { details }\end{array}$ & & $\begin{array}{l}\text { does not require the } \\
\text { memorization of too } \\
\text { many details }\end{array}$ \\
\hline $\begin{array}{l}\text { 12. is difficult to learn without external } \\
\text { support or a handbook }\end{array}$ & & $\begin{array}{l}\text { is easy to learn without } \\
\text { external support or a } \\
\text { handbook. }\end{array}$ \\
\hline $\begin{array}{l}\text { 13. forcestheusertofollow an unnecessarily } \\
\text { rigid sequence ofsteps. }\end{array}$ & & $\begin{array}{l}\text { does not force the user to } \\
\text { follow an unnecessarily } \\
\text { rigid sequence ofsteps. }\end{array}$ \\
\hline $\begin{array}{l}\text { 14. does not support easy switching between } \\
\text { individual menusor masks }\end{array}$ & & $\begin{array}{l}\text { support easy switching } \\
\text { between individual } \\
\text { menusor masks }\end{array}$ \\
\hline $\begin{array}{l}\text { 15. entails unnecessary interruptions ofthe } \\
\text { work flow }\end{array}$ & & $\begin{array}{l}\text { does not entail } \\
\text { unnecessary } \\
\text { interruptions ofthe work } \\
\text { flow }\end{array}$ \\
\hline $\begin{array}{l}\text { 16. provides errormessages which are } \\
\text { difficult to understand }\end{array}$ & & $\begin{array}{l}\text { provides errormessages } \\
\text { which are easy to } \\
\text { understand. }\end{array}$ \\
\hline $\begin{array}{l}\text { 17. error correctiongenerally requires } \\
\text { alotofeffort }\end{array}$ & & $\begin{array}{l}\text { error } \\
\text { correctiongenerally } \\
\text { requires littleeffort }\end{array}$ \\
\hline $\begin{array}{l}\text { 18. does not give concrete help for error } \\
\text { correction }\end{array}$ & & $\begin{array}{l}\text { gives concretehelp for } \\
\text { error correction }\end{array}$ \\
\hline
\end{tabular}


19. isdifficulttoexpandifnewtasks arise for me iseasytoexpandifnewtask $s$ arise for me

20. isdifficulttoadapt to my individual working style

is easilyadaptable to my

21. is, within its scope, difficult to adapt for different tasks by me individual working style is, within its scope, easy to adapt for different tasks by me

Yourcomments:

-

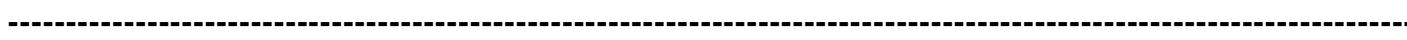

